Proceedings of JRC2005

2005 Joint Rail Conference

March 16-18, 2005, Pueblo, Colorado

RTD2005-70045

\title{
Preparations for a Train-to-Train Impact Test of Crash-Energy Management Passenger Rail Equipment
}

\author{
David Tyrell \\ Karina Jacobsen \\ Daniel Parent \\ Volpe National Transportation Systems Center \\ A. Benjamin Perlman \\ Tufts University
}

\section{ABSTRACT}

Preparations are ongoing for a full-scale train-to-train impact test of crash-energy management (CEM) equipment, during which a cab car-led passenger consist, initially moving at $30 \mathrm{mph}$, will impact a standing locomotive-led consist. The colliding consists will be of approximately equal masses. This test is planned for November 2005.

The purpose of the full-scale testing program is to define the crashworthiness performance of conventional and CEM passenger equipment. In the train-to-train test of conventional equipment, the lead cab car crushed by nearly 22 feet and overrode the standing locomotive. In the train-to-train test of CEM equipment, the leading end of the impacting cab car is expected to crush by approximately 3 feet and distribute crush to the successive car interfaces. The consist is expected to remain in-line, with no lateral buckling and override modes of deformation.

This paper describes the steps being taken to develop a CEM cab car crush zone design, based upon the recently developed and tested coach car crush zone design. The components required for an effective CEM cab car design include a push-back coupler, energy absorbing elements, a crushable anti-climber to manage the interaction with the locomotive, and a cage for preserving the operator's space. Preliminary predictions of the dynamic response of the two consists include the distribution of crush among the cars in the train and the decelerations of the cars. These predictions are compared with the measurements made during the conventional train-to-train test.

While the CEM design preserves occupant volume, the secondary impact velocities in the lead cab car and the first coach car may be more severe. Five occupant experiments will be included on the cab car and first coach car of the full-scale train-to-train impact test to ensure that the occupants are protected during the collision. These occupant experiments will include modified versions of forward-facing intercity seats, forward- and rear-facing commuter seats, and facing commuter seats with intervening workstation tables.

\section{INTRODUCTION}

The Federal Railroad Administration (FRA) has been conducting full-scale impact tests of passenger rail equipment. These tests have been organized around two collision scenarios: an in-line train-to-train collision and a grade crossing collision. The principal objective of these tests is to compare the performance of conventional and improvedcrashworthiness design equipment under similar impact conditions.

Seven of eight initially planned tests have been conducted; the eighth is the train-to-train test of crash-energy management (CEM) equipment and planned for late 2005. In this test, a cab car led consist will collide with a locomotive-led consist at 30 $\mathrm{mph}$. These test conditions are based on several train-to-train collisions, including the Prides Crossing, MA collision [1]. In the Prides Crossing collision, a commuter train traveling about 36 mph impacted an oncoming freight train traveling about 12 $\mathrm{mph}$. The test conditions are also similar to the Placentia, CA collision [2], where the commuter train was standing and the freight train was traveling approximately $22 \mathrm{mph}$.

In a train-to-train test of conventional equipment, conducted on January 31,2002 , the cab car crushed by approximately 22 feet and overrode the impacting locomotive, eliminating the survival space for approximately 47 occupants [3]. The cab car in this test overrode the locomotive in a similar manner as the cab car overrode the locomotive in the Prides Crossing collision [1]. The conventional test results established a baseline crashworthiness measure of passenger rail equipment currently in use.

The passenger equipment to be used in the upcoming test is designed to preserve the space for the operator and passengers by dispersing the structural crush into unoccupied areas of the train. The cab car is expected to crush by approximately 3 feet at the impacted end and by 2 feet at the back end of the car. Altogether, 14 feet of structural crush is predicted to occur, but this crush is distributed among all the cars of the train. 
Other tests based on the in-line train-to-train collision scenario include single car tests of conventional and CEM equipment, in which a single car impacted a fixed wall at 35 mph $[4,5]$. In the single car test of conventional equipment, the car crushed by approximately 6 feet and the wheels of the lead truck lifted off the rails by 9 inches as it crushed. In contrast, the CEM car crushed by 3 feet and all the wheels remained on the track. In two-car tests of conventional and CEM equipment, two coupled cars impacted a fixed barrier at approximately $28 \mathrm{mph}[6,7]$. The responses of the impacting car were similar to the single-car tests - the conventional car crushed by about 6 feet and rose vertically about 9 inches, while the CEM car crushed about 3 feet and its wheels remained on the rails. In the two car test of conventional equipment, the coupled cars sawtooth-buckled, and the trucks immediately adjacent to the coupled connection derailed. In the two car test of CEM equipment, the cars remained in-line, and none of the trucks derailed. These tests demonstrate that CEM equipment can successfully distribute the crush to unoccupied areas of multiple CEM vehicles and minimize both the lateral and vertical motions of the cars.

Two tests based on a grade-crossing collision scenario have also been conducted [8]. In these tests, the corner post of a cab car impacted a steel coil supported by a frangible wooden table, with the car initially traveling at $14 \mathrm{mph}$. One design tested was typical of cab car end frame designs developed in the 1990's, while the second design was compliant with rail passenger equipment regulations and standards promulgated in 1999 [9]. In the test of the 1990's design, the corner post failed and the operator's survival space was eliminated. In the test of the State-of-the-Art design, the corner post remained attached and the operator's survival space was preserved.

\section{TEST DESCRIPTION}

Figure 1 shows a schematic of the train-to-train impact test. In this test, a moving cab car led train impacts a standing locomotive-led train. The locomotive-led train includes two hopper cars, ballasted such that both trains weigh nearly the same. The impact locomotive is an EMD F40 compliant with the AAR S580 standard [10]. The cab car led train includes four coach cars and a trailing locomotive. The passenger car consist is typical of a commuter push-pull consist with a locomotive at one end, leading into a city and a cab car at the other to lead away from the city. The impact occurs on tangent track, with the cab car led train initially traveling at $30 \mathrm{mph}$.

A CEM end structure will be installed on each end of each passenger car. The interfaces contacting a locomotive (front end of the lead cab car and the rear end of the coach car adjacent to the rear of the locomotive) will have a cab car end frame that includes features such as a deformable anti-climber, pushback operator's cage and crushable components (similar to the CEM coach car design). The cab car CEM equipment is currently in the design process. The coach car crush zone design tested in the single- and two-car tests of CEM equipment is being adapted to a Budd M1 passenger car, and will be installed on three cars. The two Pioneer cars used in the single- and two-car tests of CEM equipment are currently being repaired for use in the train-to-train test.

Simulations of the test are currently being conducted in order to verify that the CEM design will function as intended and to determine the size and placement requirements for the structural instrumentation. These simulations are intended to assure that the final crush-zone designs limit the potential for override of the colliding equipment, and propagate the crush among all the cars of the train. Instrumentation will include accelerometers on all the cars, displacement transducers on the car suspensions and on the crush zones, strain gages at selected locations, and high- and conventional-speed cameras.

Occupant experiments will be included as part of the trainto-train test of CEM equipment. The interior configurations to be tested include facing seats with an intermediate table, forward-facing commuter seats, and rear-facing commuter seats. All of the interior configurations to be tested include features to increase occupant protection over conventional designs.

\section{CAB CAR DESIGN DEVELOPMENT}

The objectives of the cab car crush zone are three-fold: preserve the operator space, preserve the passenger space, and manage the collision for a range of geometries of the colliding equipment. Therefore, the crush-zone design in the cab car must fulfill more design requirements than the coach car. To achieve these goals, the cab car design relies on concepts developed in the coach car crush zone design [11] and a study of effective anti-climbers [12].

The basic concept of crash-energy management is that the end structure crushes in a controlled manner during an impact. Additional features of the cab car include a crushable anticlimber that conforms to the geometry of the colliding equipment and spreads the load across an integrated end frame that can pushback during a collision and preserve the operator space. This crush zone is capable of absorbing at least 2.5 million foot-pounds of energy, and can function as a coach car crush zone. This design also meets all of the current FRA regulations and APTA standards for cab car crashworthiness, including the 800 kip buff load requirement, as well as all of the collision and corner post requirements. A car with this end structure remains within the geometric limits for traversing a curve coupled to another car and can couple with conventional rail passenger equipment.

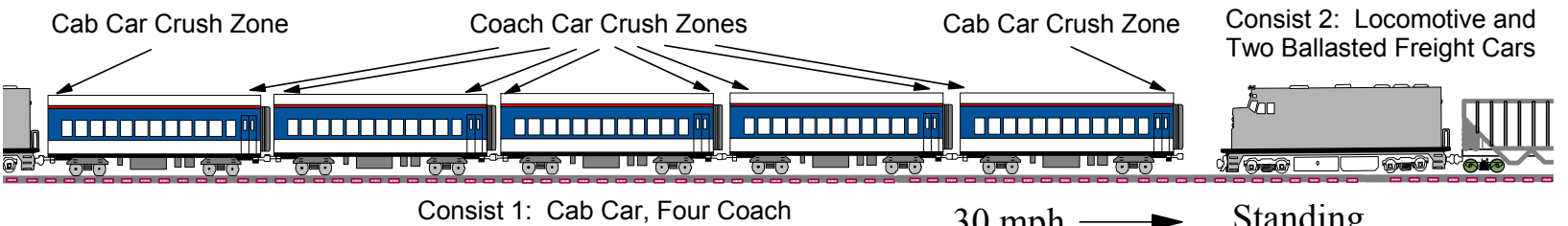

Figure 1. Schematic of Train-to-Train Test 
Figure 2 shows a schematic of the cab car crush zone conceptual design. This concept includes four key elements:

1. A deformable anti-climber arrangement

2. A push-back coupler mechanism

3. An integrated end frame, which incorporates an operator volume

4. Roof and primary energy absorbing elements

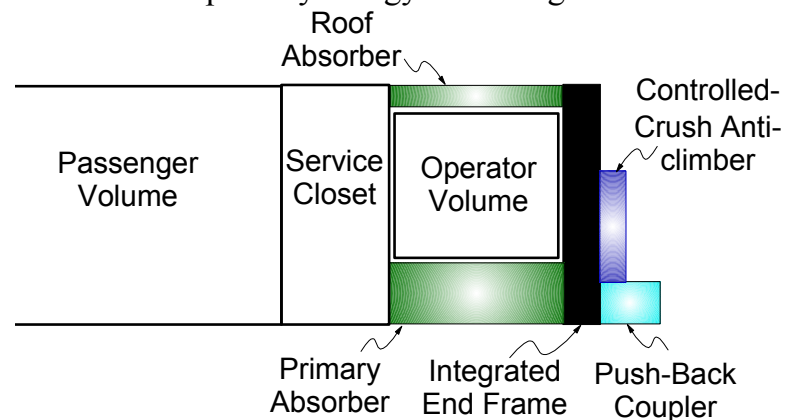

Figure 2. Cab Car Crush Zone Conceptual Design (Side View)

The activation of the push-back coupler initiates the crush zone and provides a mechanism that allows each component to operate in sequence. When the coupler triggers and pushes back, an energy absorbing element crushes. The travel of the shear-back mechanism accommodates the coupler of the impacting equipment to the extent necessary for the anticlimber and integrated end frame to engage the impacting equipment appropriately.

As the anti-climber begins to deform it incorporates the geometry of the locomotive and distributes the load over as large an area on the integrated end frame as can be reasonably achieved. As a goal, the collision posts should carry $60 \%$ of the crushable anti-climber loads and the corner posts $40 \%$. The anti-climber is designed to crush in a controlled manner and must avoid forming a ramp or a catapult by limiting the potential for material failure. The anti-climber must sustain off-center impact loads and be able to transmit longitudinal loads into the end frame.

The integrated end frame is designed to remain sufficiently stiff in transmitting the impact load to the energy absorbers to assure the proper functioning of these elements. The integrated end frame can appropriately trigger and allow crushing of the energy absorbers when the coupler and the anti-climber share the impact load, or when the load path is through only the coupler or the crushable anti-climber. The structure attached for assuring survival volume of the operator can be pushed straight back into space normally taken by electrical and/or brake service closets. The expected structural deformation does not interfere with ready egress from the operator's compartment before and after the design crush zone stroke has been exhausted. The structure allows for the operator's seat to be attached with sufficient security to remain attached during the test. (Means of protecting the operator from the expected decelerations are currently being explored, including the use of inflatable structures [13].)

When the integrated end-frame is subject to a high-energy impact load, the cab car crush zone deforms in a controlled manner, activating both the roof and primary energy absorbers.
The energy absorbers are able to properly function while accommodating the deflections of the integrated end frame. These devices can absorb more than 2 million foot-pounds of energy.

A conventional carbody structure, between the two body bolsters (i.e., the underfloor structures at each end of the car that provide support for the suspension), is sufficient to support the loads from the cab car crush zone as it crushes over its design stroke. The cab car crush zone design is being developed for retrofit onto an existing M1 car.

Figure 3 shows the preliminary force/crush characteristic for the cab car crush zone conceptual design. This force/crush characteristic is fundamentally similar to the one for the coach car crush zone design, with some differences. In order to accommodate impacts with equipment that have conventional couplers, the stroke of the push-back coupler (PBC) absorber is longer. A crushable anti-climber (AC) is required to accommodate a range of potential impacting equipment, locomotives, as well as other cab cars of various designs. The primary and roof energy absorbers are essentially the same as previously developed for the coach car crush zone.

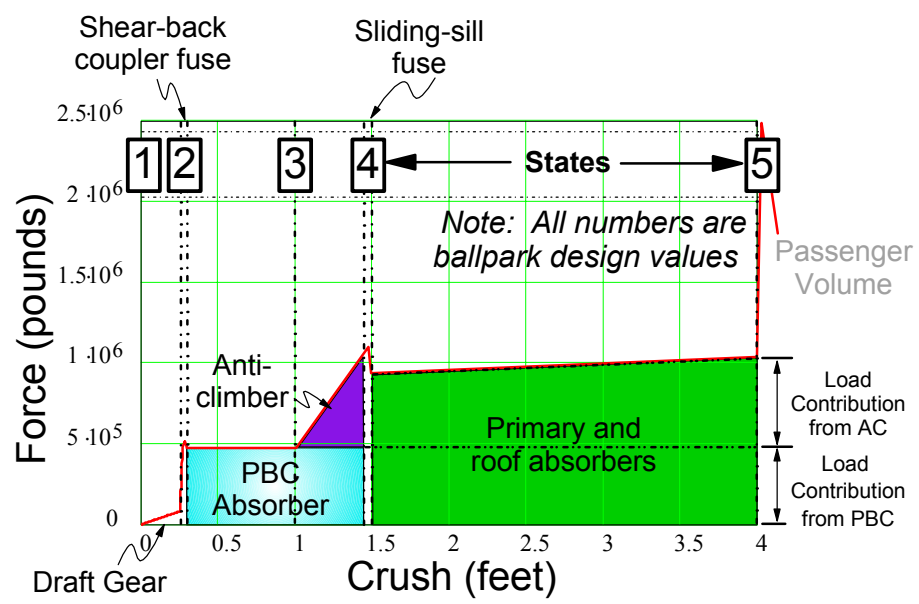

Figure 3. Preliminary Force/Crush Characteristic for Cab Car Crush Zone Conceptual Design

Figure 4 illustrates the desired kinematics of the cab car crush zone conceptual design during an impact with a conventional locomotive. Initially the couplers meet, in state 1 . The stroke of the draft gear is eventually exhausted; the load increases on the structural fuse, which then releases in state 2. In state 3, the anti-climber is also engaged, and the load is shared between the anti-climber and the coupler. When the combined load on the coupler and anti-climber is sufficient, the energy absorber structural fuse releases in state 4. The primary and roof absorbers crush and reach state 5 when their stroke is exhausted.

The cab car crush zone is being designed to function for a range of initial conditions. It is designed to function for lateral and vertical misalignments of the colliding bodies of up to 3 inches, pitch and yaw of the cab car body of up to 0.4 degrees and pitch and yaw of the colliding locomotive of up to 0.5 degrees. These limits correspond to an end-to-end difference in elevation of approximately 6 inches for both the cab car and the locomotive. 
Development of the design has progressed to the point where its interaction with an impacting locomotive can be simulated. The colliding equipment simulation techniques used to evaluate the conventional train-to-train test [14] are being applied to assure the functioning of the cab car crush zone under the full range of potential test conditions. The modeling will allow further refinement of the design. Once a design has been developed with satisfactory performance, detailed drawings will be generated, components will be built, and will be retrofitted onto an existing M1 passenger car.

\section{States}
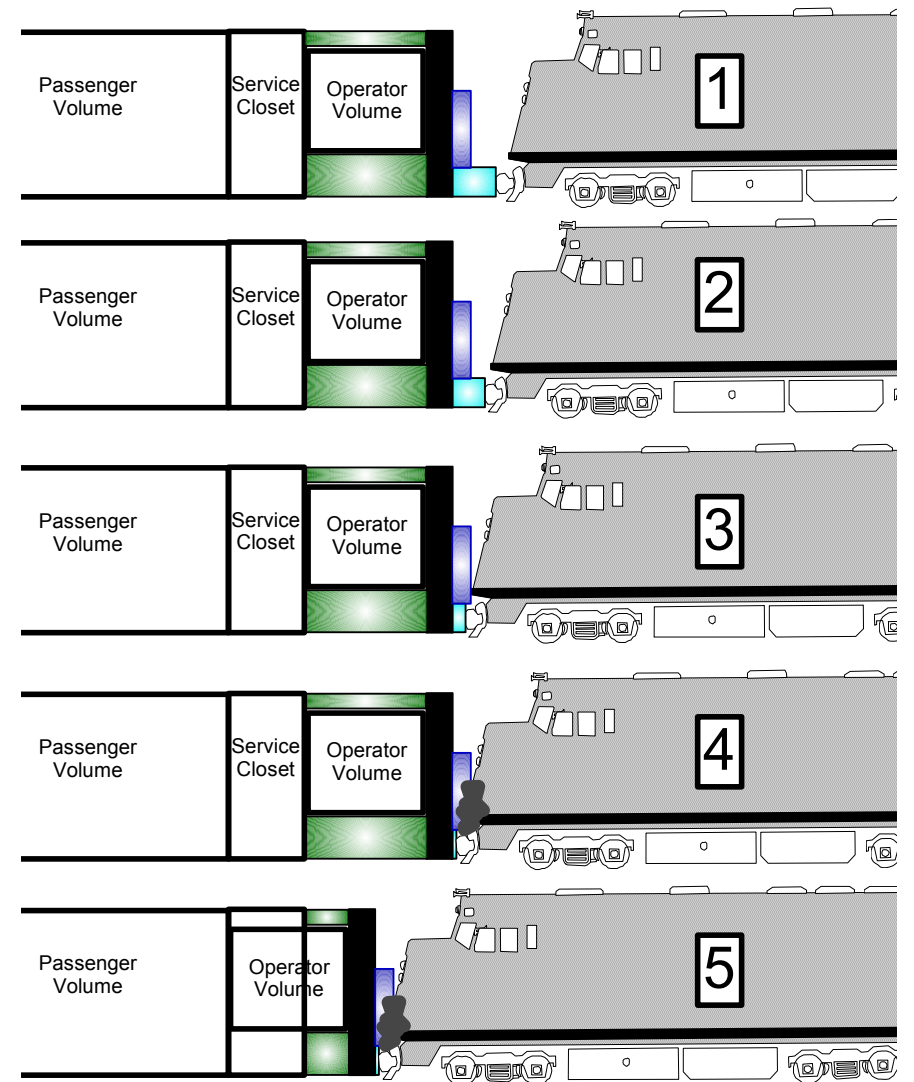

Figure 4. Desired Kinematics for Cab Car Crush Zone Conceptual Design

\section{EQUIPMENT DESIGN AND CONSTRUCTION}

Two cab cars and three coach cars are being modified with crush zones for the train-to-train test of CEM equipment. The Pioneer coach cars tested in the single-car [5] and two-car test [7] of CEM equipment have been repaired. The previously tested coach car crush zone design has been adapted to the M1 car. Coach car crush zones are being retrofitted to both ends of one M1 car. Two additional M1 cars will have a cab car crush zone on one end and a coach car crush zone on the other end.

\section{Pioneer Coach Cars}

Figure 5 is an illustration from the finite-element crush model of the Pioneer coach car crush zone, showing the principal components. Shear bolts act as a structural fuse, and keep the buff lug in place until a load of approximately 500 kips is reached. Once these bolts shear, the buff lug is pushed back by the coupler, crushing aluminum honeycomb. After the coupler has been pushed back, the end frame provides an additional load path. The sliding sill pushes back into the fixed sill when the combined load into the coupler and end beam reach the load required to trigger the structural fuse for the primary and roof energy absorbers. Shear bolts connect the sliding sill to the fixed sill and shear rivets connect the inner tube to the outer tube of the roof absorbers and act as structural fuses; the trigger load is approximately 1.2 million pounds. The details of this design are described further in the reference [11].

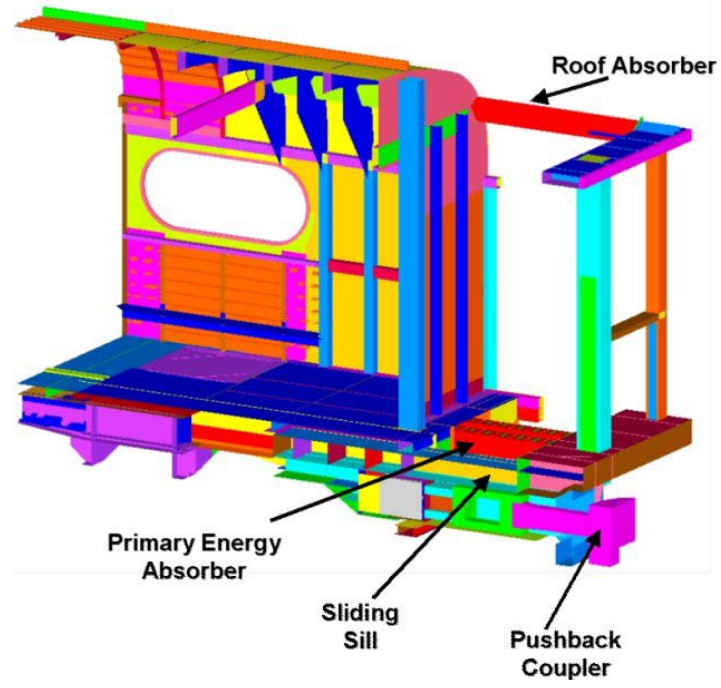

Figure 5. Pioneer Coach Cars, End Frame Design Schematic

Figure 6 shows the two Pioneer coach cars shortly before the two-car impact test. Major components - the end frame, sliding sill, fixed sill - were fabricated and shipped to TTC in Pueblo, CO. These components were installed by TTCI, who also cut and prepared the cars and fabricated the smaller components. After the single-car and two-car test, all of the energy absorbing elements - the primary, roof, and pushback coupler - had received at least some crush. New primary energy absorbers were fabricated and installed. New aluminum honeycomb in the pushback couplers and the roof absorbers, and new shear bolts and rivets were also installed. The repair of these crush zones has been completed.

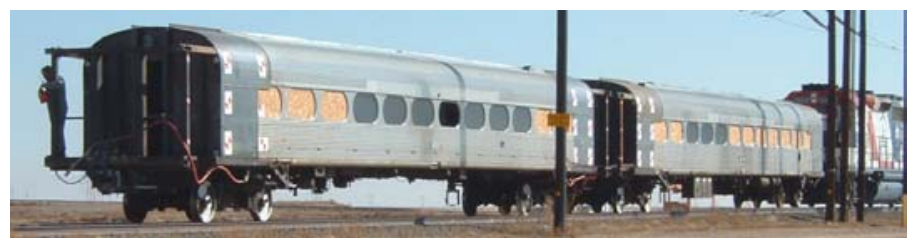

Figure 6. Pioneer Coach Cars, Shortly Before Two-Car Impact Test

\section{M1 Coach Car}

The original Pioneer and M1 cars were both designed and built by the Budd Company. The designs of these cars share many similarities, but there are also distinct differences. The center sills of both cars are identical, and the side sills are very similar - the side sills have nearly the same area and areamoment properties, but different shapes. The body bolsters are 
different. The principal lateral members of the Pioneer body bolster have a shallow V shape, and attach to the bottom of the draft and center sills. The lateral members of the M1 body bolster are flat, and effectively pass through the draft and center sills.

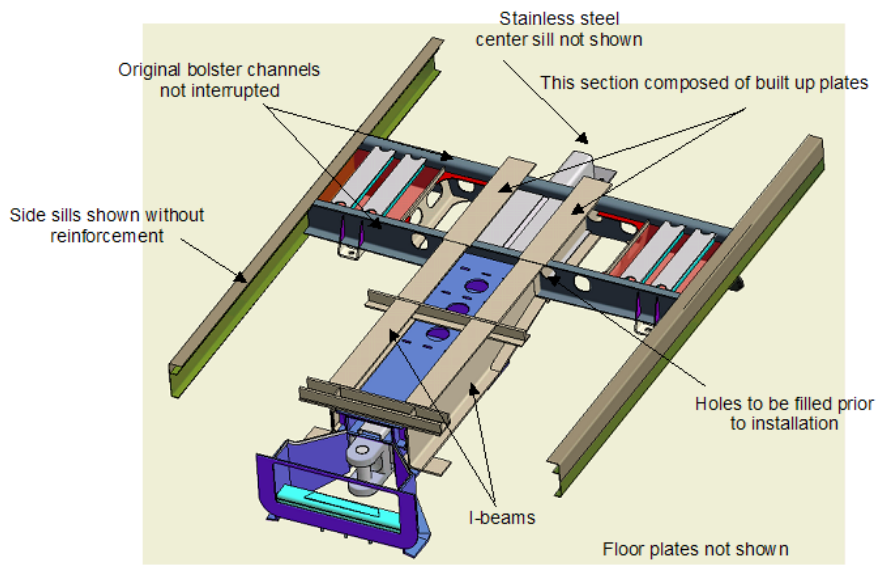

Fixed Sill Integration with Center Sill Stub and Bolster

Figure 7. Crush-zone Draft Sill Integration with M1 Car Body Bolster and Center Sill

The most challenging aspect of adapting the Pioneer coach car crush zone has been the integration of the fixed (draft) sill with the body bolster of the M1 car. Figure 7 shows a drawing from a CAD model of the fixed/sliding sill and the M1 body bolster. Placement of the roof absorbers has also been altered for the M1 car. The drawing does not show the placement of the primary energy absorbers. The body bolster will be further reinforced than is shown in the figure, and the supports and energy absorbers will be added. The side sills outboard of the body bolster will be selectively reinforced to help support the primary energy absorbers. The side sills and center sills inboard of the body bolsters will not be altered.

The cross-sectional geometry of the M1 carbody is different from the Pioneer carbody. The shape of the M1 has allowed the rectangular cross-section roof absorbers to be squarely placed, while they were canted at approximately $45^{\circ}$ angle in the Pioneer cars. More of the original roof will be retained in the M1 cars than was retained in the Pioneer cars, owing to the differences in carbody cross-section and the somewhat less restricted placement of the roof absorbers in the M1 cars.

The cars are currently being prepared for integration of the crush zones. The coach car crush zone will be retrofitted to two ends of one car and to one end of two cars (see Figure 1). TTCI is currently cutting the original ends from these cars, and preparing them for the installation of the crush-zone components. Drawings are being finalized, and parts are expected to ship from Ebenezer by the time of the 2005 ASME/IEEE Joint Rail Conference.

\section{M1 Cab Cars}

Figure 8 shows a CAD drawing of the current iteration of the cab car crush zone design. Principal differences with the coach car crush zone include the addition of the crushable anticlimber and the operator survival volume. The anti-climber is comprised of short rectangular tubes that support a stiff plate.
This arrangement is intended to spread the load from an impacting vehicle into both the collision and corner posts. The operator's survival volume is intended to push back into the electrical and brake service closets. Additional differences include a longer push-back coupler stroke, to accommodate an impact with equipment which does not have a push-back coupler, and a center lug on the anti-telescoping plate, to engage the short hood of an impacting locomotive.

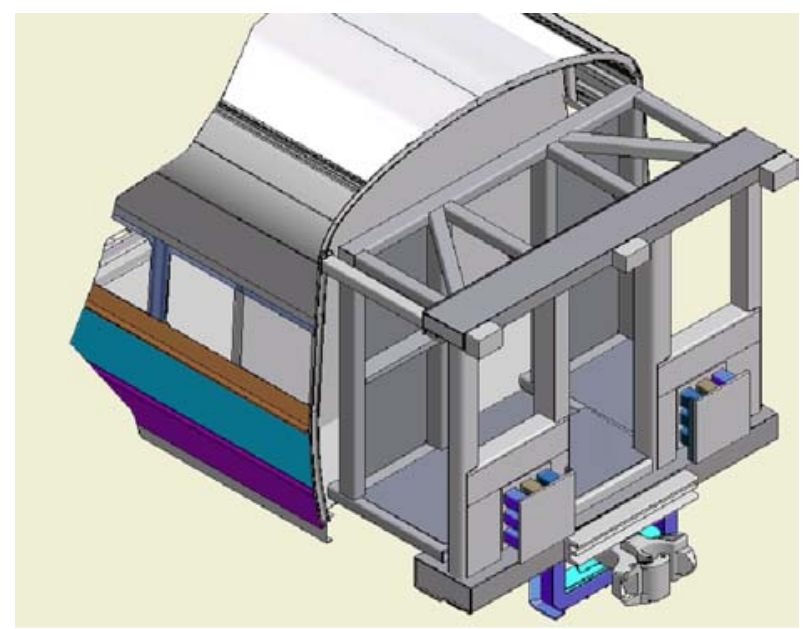

Figure 8. M1 Cab Car Crush Zone Draft Design

The electrical and brake service closets in cab cars are arranged to allow repair personnel access to the equipment inside. Figure 9 shows photographs of these service closets in an MBTA cab car manufactured by Kawasaki. The electrical closet is directly behind the operator's cab. The brake closet is behind the electrical closet. It is assumed that the brake closet could be located across the aisle from the electrical closet in a new car design.
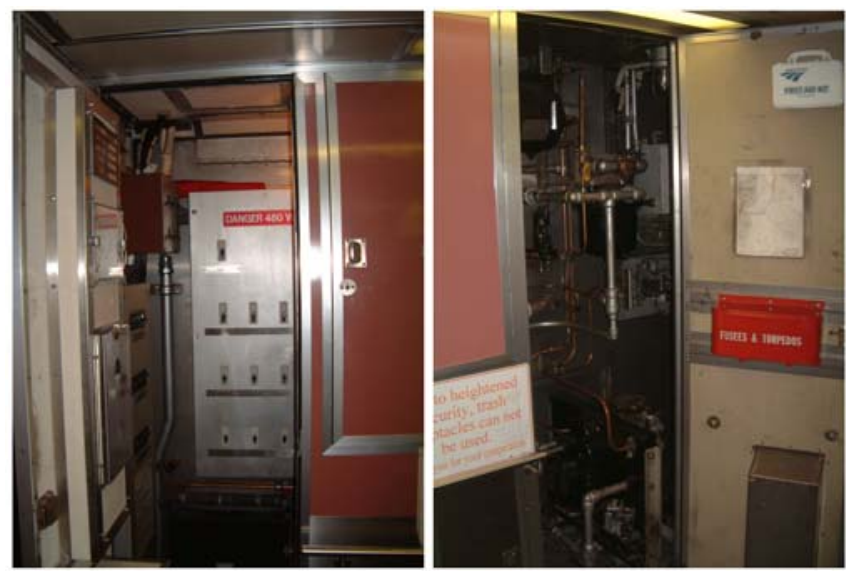

Figure 9. Electrical and Brake Service Closets, MBTA Commuter Car, built by Kawasaki

Impacts of the cab car with an F-40 locomotive are currently being simulated with a detailed finite-element model in order to refine the cab car crush zone design. These analyses are being used to help guide the selection of material, as well as to finalize the details of the geometry. Once key details of the design have been resolved, then design drawings will be made. Like the coach car crush zone design, the major components 
will be constructed from the design drawings, and then installed by TTCI, who will also use a set of integration drawings to guide retrofit of the cars. Two cab car crush zones will be retrofitted onto two M1 cars. These cars will have coach car crush zones on the opposite ends.

\section{STRUCTURAL TEST REQUIREMENTS}

One-dimensional and three-dimensional collision dynamics models are currently being used to simulate the test, in order to estimate the crush distribution and the gross motions of each of the cars in the two trains. The current estimate of the cab car force-crush characteristic (see Figure 3) was used for the two crush zones contacting locomotive ends (see Figure 1) and the force-crush characteristic developed and measured for the CEM coach cars [7] was used as the crush behavior for all other passenger car ends. These simulations are being conducted in order to help range and locate the instrumentation to be used during the test.

\section{CRUSH COMPARISON}

Figure 10 shows the distribution of crush among the cars in the CEM consist. The amount of crush sustained by an individual car end and the total amount of damaged occupant volume in each passenger car is summed in each bar.

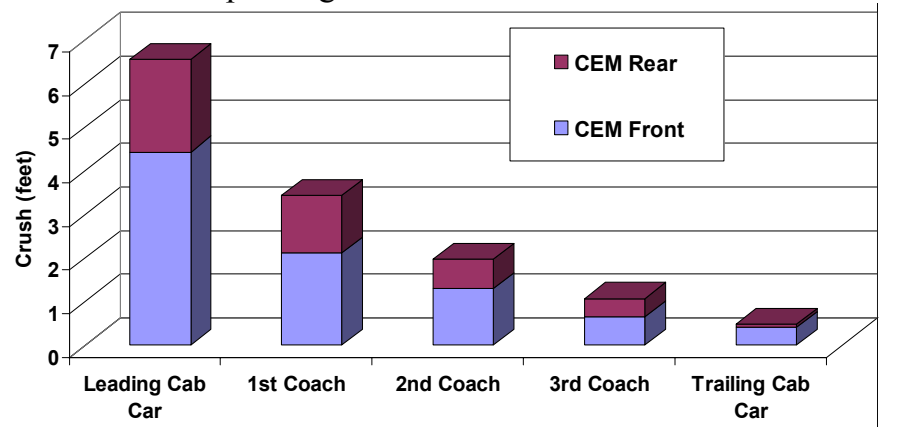

Figure 10. Crush Distributions

In the train-to-train test of conventional equipment, the impacted end of the leading cab car crushed by approximately 22 feet and the impact end of the leading locomotive sustained minor structural damage. There was no other structural damage observed in this test. The cab car overrode the locomotive during the test, in spite of the underframe of the cab car being substantially lower than the underframe of the locomotive. The force-crush characteristic of conventional passenger cars prevents the distribution of crush to successive cars. After a single high peak load is exceeded (structurally corresponding to the fracture of the draft sill), the car continues to crush at a relatively low uniform load.

The crush distribution plot in Figure 10 shows how the crush will be shared between the crush zones of the CEM consist. At the $30 \mathrm{mph}$ impact speed, the crush zone of the lead cab car is nearly exhausted; crush is passed back to the following crush zones. Each car in the CEM system is characterized by an increasing, stepped force-crush behavior. When the force level on the first crush zone reaches the second step, and the primary energy absorbers crush, force levels also begin to be passed to the successive cars causing those crush zones to trigger. Because the pushback couplers trigger at a lower load than the primary energy absorbers, crush is distributed to additional crush zones before the third peak load level is exceeded at the lead crush zone.

The CEM crush behavior in this collision scenario indicates that energy absorption will be shared by multiple crush zones, consequently preventing damage to the occupied areas of the cars. An initial kinetic energy of 19.3 million $\mathrm{ft}-\mathrm{lbs}$ is calculated from the current estimates of the consist's mass and the anticipated initial speed. Each crush zone is designed to absorb at least 2.5 million ft-lbs. Approximately 14 feet of crush are estimated to be distributed among the crush zones.

\section{GROSS MOTIONS}

Figure 11 shows the simulation results for the velocity timehistories of each of the cars in the CEM passenger consist and the lead locomotive of the initially stationary freight consist. The lead car impacts the freight consist and begins to crush causing it to initially decelerate the fastest. As each crush zone is progressively triggered, each successive car decelerates at a similar rate to the first car. With the preliminary force crush behavior used in this simulation, the last crush zone did not trigger. Consequently, the trailing car and the locomotive decelerate together, essentially moving as a single mass. Both the passenger and freight consists move together down the tracks at approximately $10 \mathrm{mph}$ by 0.75 seconds after the impact. The corresponding conventional test took nearly 2 seconds for the crushing to complete and two consists to reach the same speed.

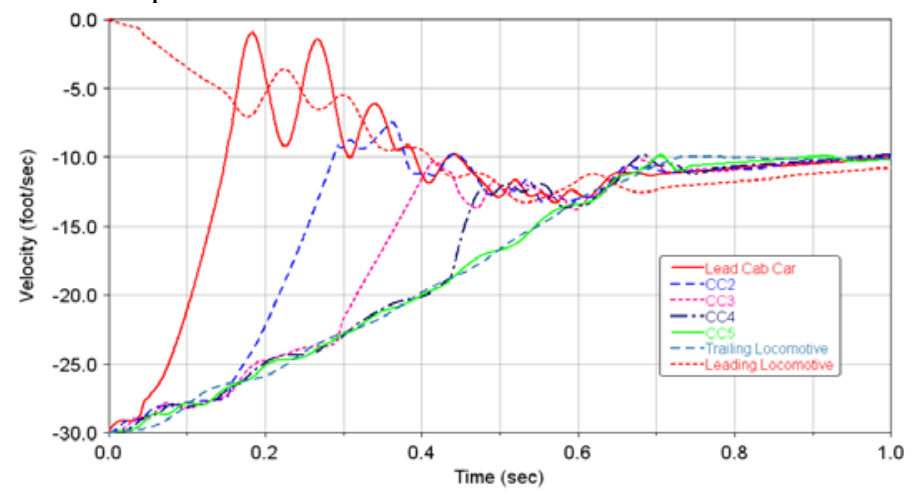

\section{Figure 11. Velocity Predictions}

The decreased overall collision time of the CEM test indicates that the passengers will experience more severe decelerations than in the conventional test. Figure 12 shows a plot of the secondary impact velocities (SIVs) in the cab car led train for both the conventional and CEM consists. Secondary impact refers to the impact between the occupant and some part of the interior, usually the forward seat, table or bulkhead. Secondary impact velocity is the relative velocity difference between the occupant and the rail car itself at the point of impact. Generally, higher secondary impact velocities correlate with increased injury risk. The SIV gives an initial indication of the relative severity of the occupant environment.

The average allowable occupant displacement (if compartmentalized) for common seating configurations is indicated in Figure 12. The largest distance traveled is associated with seats located behind a bulkhead; this seating configuration accounts for the fewest number of seats in a car. The most common seating configurations in commuter and 
intercity cars are forward-facing seats and allow for 2-2.5 feet of respective longitudinal occupant displacement. Occupants seated at tables may travel 10-12 inches. Rear-facing seats allow for no relative displacement, providing the highest level of safety associated with secondary impacts.
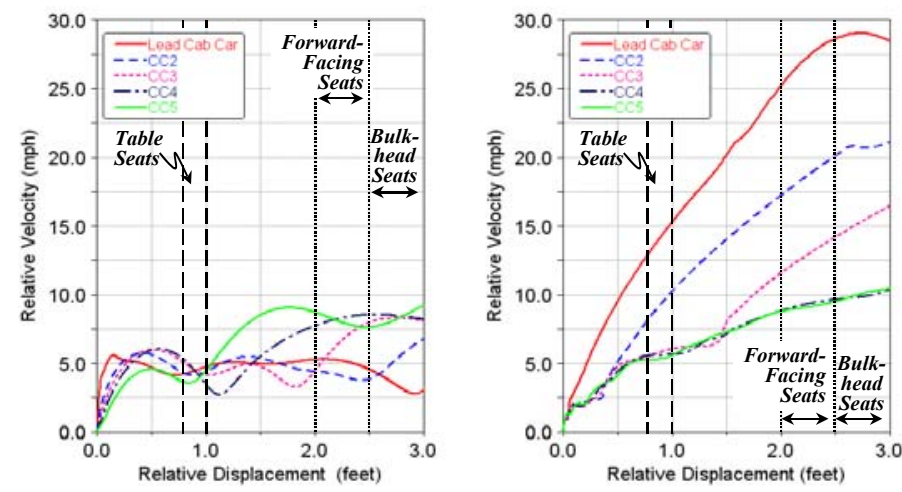

Figure 12. Secondary Impact Velocities of Conventional (left) and CEM (right) Passenger Cars

The ability of the CEM passenger cars to preserve the occupied volume of the car comes at a cost of a more harsh secondary impact environment for some of the cars in the consist. In a collision involving a multiple-car passenger consist, the most severe secondary impacts will be seen towards the front of the consist, while the secondary impacts will be gradually less severe for cars towards the rear of the consist. As can be seen in the secondary impact velocity plot presented in Figure 12, the CEM cab car is predicted to have an occupant environment notably more severe than that of the conventional cab car under similar test conditions. The first and second coach cars have SIVs that are between the cab car and the coach cars furthest from the impact. The third and fourth CEM coach cars have essentially the same SIV as their counterparts in the conventional consist.

\section{REQUIREMENTS FOR OCCUPANT PROTECTION EXPERIMENTS}

In the CEM full-scale two-car impact test, five occupant experiments were carried out in various seating arrangements. These arrangements consisted of forward-facing intercity seats, forward- and rear-facing commuter seats, and facing commuter seats with intervening workstation tables. The results of these experiments indicated several areas for improvement of the seating arrangements [15]. The occupant experiments to be conducted on the CEM full-scale train-to-train impact test will consist of a similar group of seating arrangements, including the suggested improvements. The occupant experiments and their placement in the cars are depicted in Figure 13 and Figure 14.

There are two necessary elements to protect occupants during a collision. It is first necessary to compartmentalize the occupants. Compartmentalization refers to limiting the trajectory of the occupant, usually within the space between the launch seat and the impacted seat. If compartmentalization is lost, the occupant kinematics are less predictable, and there exists a risk of striking more volatile surfaces. Compartmentalization has been shown to be an effective occupant protection strategy [16]. Second, the loads and accelerations imparted on the occupants by the seating arrangements that act in compartmentalizing the occupants must be within maximum injury criteria values. These two necessary elements are evaluated by the five occupant experiments.

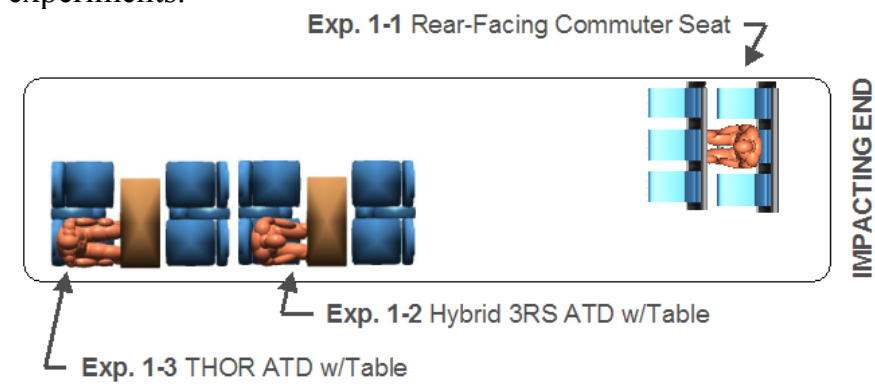

Figure 13. Location of Cab Car Occupant Experiments

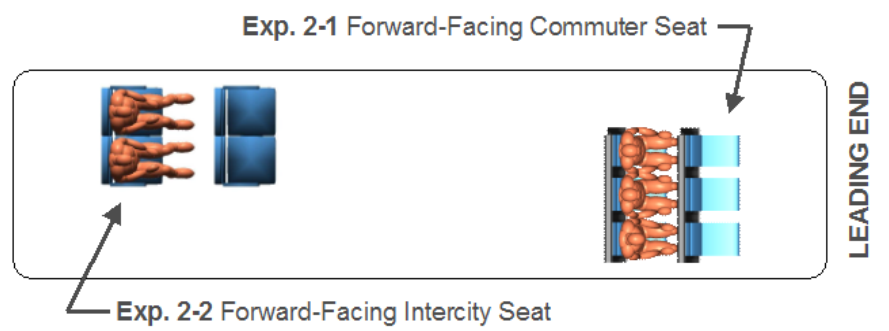

Figure 14. Location of $1^{\text {st }}$ Coach Car Occupant Experiments

\section{DESCRIPTION OF OCCUPANT EXPERIMENTS}

All five of the occupant experiments use versions of seating arrangements that have been previously included in the conventional full-scale tests, CEM full-scale tests, and in sled testing. These seats have been modified as determined necessary from each testing iteration. A secondary objective of these tests is to gather data to refine computer models of each occupant experiment. As more test data is collected on each seat type and configuration, the computer models can be used more reliably to estimate the injury risk of many different collision scenarios. This data can also be used to evaluate the effectiveness of seat modifications.

The occupant experiments will include several different anthropomorphic test devices (ATDs, or test dummies) to measure the occupant response during the collision. These ATDs will be instrumented to measure head acceleration, chest acceleration, neck loads and moments, femur loads, chest compression, abdominal compression, and abdominal loads where appropriate. The seating arrangements will be instrumented to measure the attachment loads of the seats and tables, as well as the local car body accelerations. Additionally, high-speed video cameras will record the motion of the occupants during the collision, which will later be measured using photometric methods. The data captured during these experiments will be analyzed to determine the injury risk to occupants in each of the seating arrangements, as well as to refine computer simulations. 
Experiment 1-1 - Rear-Facing Commuter Seats, One $50^{\text {th }}$ Percentile Male ATD, Cab Car

Since the secondary impact environment in the cab car during the collision of a CEM passenger consist is more severe than in conventional equipment, further steps must be taken to protect the occupants. Previous testing has shown that rearfacing seats are an effective occupant protection strategy [17]. In order to verify this occupant protection strategy, a rearfacing seating arrangement will be included on the cab car in the CEM train-to-train impact test. Figure 15 is an illustration from the simulation model of this occupant protection experiment.

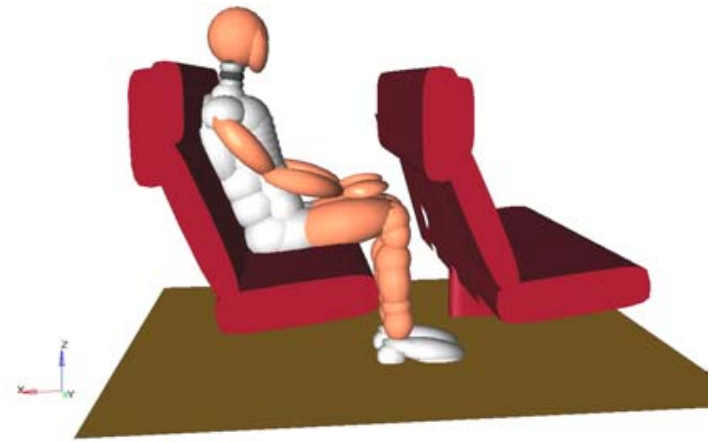

\section{Figure 15. Experiment 1-1 - Rear-Facing Commuter Seats}

Experiment 1-1 will consist of two rows of rear-facing three-person M-Style commuter seats. One Hybrid III $50^{\text {th }}$ percentile male ATD will be seated at the middle position in the row nearest the impacted end of the cab car. This row of seats will be modified based on the results of previously conducted experiments (including conventional full-scale tests, CEM fullscale tests, and sled tests) as well as a series of computer simulations. A commuter seat that employs an optimized forcedeflection characteristic is currently under development; this seat will both compartmentalize and minimize the injury risk to the occupant. The objectives of this experiment are to ensure that the seat attachment strength and degree of seatback deformation are sufficient to compartmentalize the occupant, to determine the overall occupant injury risk, and to show that rear-facing seats are an effective occupant protection strategy.

\section{Experiments 1-2 and 1-3 - Facing Seats with Tables,} Hybrid 3RS and THOR ATDs respectively, Cab Car

Two new experiments were conducted on the CEM fullscale two-car impact test. These experiments examined the occupant response in the facing-seat arrangement with an intervening workstation table. The impetus for these experiments was a rail accident in which a MetroLink passenger train collided with a BNSF freight train in Placentia, CA on April 23, 2002. Two of the three fatalities, along with several serious injuries, were likely caused by thoracic and abdominal injuries due to impact with a workstation table [2]. The results of these experiments confirmed a high risk of serious to fatal thoracic and abdominal injury from impact with the workstation tables. Figure 16 is an illustration from the simulation model of this occupant protection experiment.

An improved workstation table is currently in development. The improved table will remain attached to the wall and floor of the car to ensure that the occupant is compartmentalized; distribute the abdominal load over a larger area to decrease penetration into the abdominal cavity; and limit the load imparted on the occupant during impact. These characteristics will reduce the risk of serious to fatal thoracic and abdominal injury. These experiments will include both the THOR $50^{\text {th }}$ percentile male ATD and the Hybrid III Rail Safety $50^{\text {th }}$ percentile male ATD that were used in the CEM full-scale twocar impact test, so that the benefit of the improved workstation table can be assessed directly.

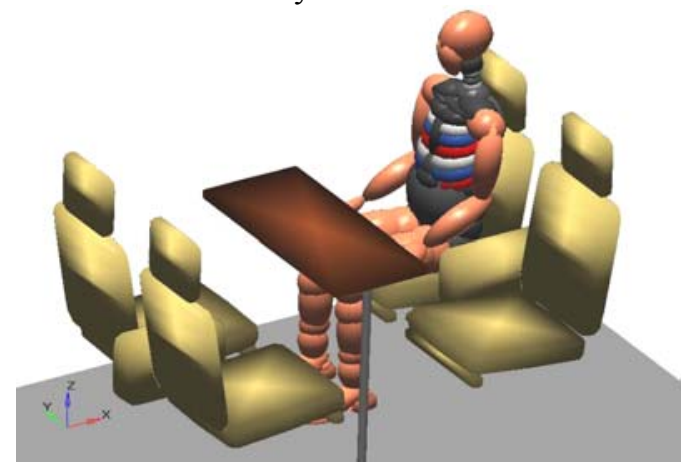

Figure 16. Experiments 1-2 and 1-3 - Facing Seats with Tables

The objectives of Experiments 1-2 and 1-3 are to determine the crashworthiness behavior of the modified workstation tables in the facing-seats configuration, as well as to verify the decrease in injury risk to the occupants impacting the tables. Another objective of the table experiments is to continue collecting and comparing test data from the two experimental ATDs (THOR and Hybrid 3RS) subjected to the same collision conditions.

\section{Experiment 2-1 - Forward-Facing Commuter Seats, Three $50^{\text {th }}$ Percentile Male ATDs, $1^{\text {st }}$ Coach Car}

On the CEM full-scale two-car impact test, the severe secondary impact environment of the trailing car brought about significant deformation of the forward seatback in the forwardfacing commuter seat arrangement. This effect was also seen in the full-scale one-car test of conventional equipment, which had a similarly severe secondary impact environment [18]. This seatback deformation led to the loss of compartmentalization of all three occupants in this seating arrangement. As compartmentalization is the first requirement for occupant protection, modification of the forward-facing commuter seats is necessary. Figure 17 is an illustration from the simulation model of this occupant protection experiment.

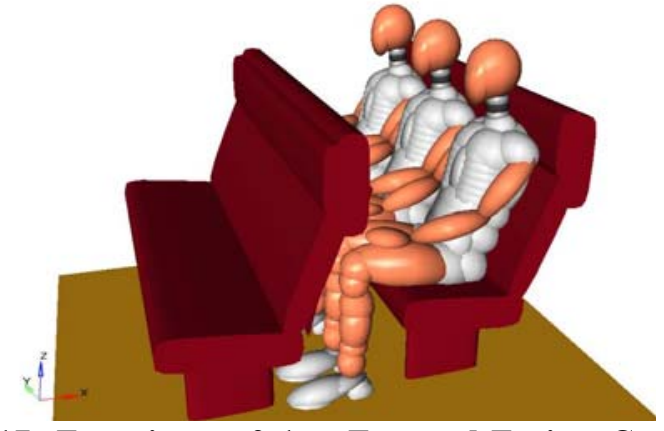

Figure 17. Experiment 2-1 - Forward-Facing Commuter Seats 
The forward-facing commuter seats included in Experiment 2-1 will be identical to the seats used in Experiment 1-1. These seats have been modified to employ an optimized forcedeflection characteristic that will both compartmentalize and minimize the injury risk to the occupant. The objectives of this experiment are to ensure that the seat attachment strength and degree of seatback deformation are sufficient to compartmentalize the occupants; to determine the overall injury risk to the occupants; and to ensure that the optimized forcedeflection characteristic of the modified commuter seat is effective to protect occupants in both forward-facing and rearfacing arrangements.

\section{Experiment 2-2 - Forward-Facing Intercity Seats, Two} $95^{\text {th }}$ Percentile Male ATDs, $1^{\text {st }}$ Coach Car

On the CEM full-scale two-car impact test, forward-facing intercity seats were successful at compartmentalizing two $95^{\text {th }}$ percentile male ATDs. Most of the injury measurements were below the maximum injury criteria values. However, the measured acceleration brought about from the impact of the heads of the ATDs and the forward upper seatbacks indicated a HIC of four to five times the acceptable tolerance level. The duration of the measured head accelerations was extremely short, and associated with a very small overall change of velocity. Computer simulations have shown that employing a softer impact stiffness between the head and the upper seatback can greatly reduce the risk of serious to fatal head injury without increasing neck loads. Figure 18 is an illustration from the simulation model of this occupant protection experiment.

The forward-facing intercity seats, which will be installed in the $1^{\text {st }}$ coach car of the passenger consist, will be modified based on the results of previously conducted experiments as well as on a series of computer simulations. Additional padding will be added to the upper seatback of the forward seat to protect against a severe head impact. The objectives of this experiment are to ensure that the degree of seatback deformation is sufficient to compartmentalize the occupants, as well as minimize the overall injury risk to the occupants.

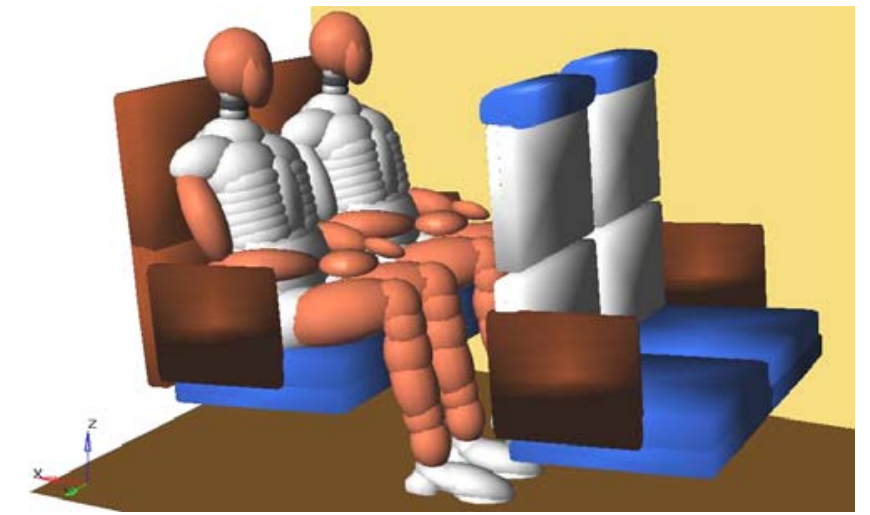

Figure 18. Experiment 2-2 - Forward-Facing Intercity Seats

\section{SUMMARY}

The foremost goal of improving rail passenger equipment crashworthiness is to preserve the occupant volume during a collision. The secondary goal is to enable the passengers to ride out the collision by minimizing secondary impact velocities and providing a "friendly" interior environment. Crash energy management along with strategic modification of rail passenger interior components has the potential to significantly increase occupant protection during an accident.

An ongoing series of in-line full-scale impact tests of conventional and CEM passenger equipment is nearing completion. In the sixth and final in-line test, currently scheduled for late 2005, a cab car led passenger consist will impact a standing locomotive led consist. The CEM coach car end structure that was tested in both one-car and two-car fullscale impact tests will be installed on the ends of each passenger car. A CEM end structure designed specifically for a cab car is currently being developed. It will include additional components such as deformable anti-climbers and a pushback operator's cage. This energy absorbing cab car structure will be installed on the colliding interface, as well as the interface between the fourth coach car and the trailing locomotive.

In the train-to-train test of conventional equipment, the space for approximately 46 passengers and the operator was destroyed. Under the same impact conditions, the CEM equipment is expected to preserve the space for all of the occupants. However the secondary impact velocities in the cab car and first coach car are likely to be higher than in the conventional equipment.

In order to reduce the injury risk to the occupants in this more severe environment, modifications to the interior arrangements are being made to keep secondary impact forces and decelerations within survivable limits. Five experiments will be included on the full-scale train-to-train impact test to measure the occupant response in modified versions of previously-tested seating arrangements: forward-facing intercity seats, forward- and rear-facing commuter seats, and facing commuter seats with intervening tables. These modifications are expected to minimize the injury risk to the occupants.

As part of the rail passenger equipment crashworthiness research, studies have been conducted to evaluate the influence of operational factors in train-to-train collisions [19, 20, 21]. These studies show that CEM cars can be introduced into service with minimum risks and with great potential benefit. The crashworthiness performance of a consist which is a mix of conventional and CEM equipment is never worse than the performance of an all conventional equipment consist in a train-to-train collision, and is always better when a CEM car is the impacting cab car. The impacting end of a CEM car can absorb more energy before intrusion into the occupant volume than the impacting end of a conventional car. Consequently, the impact speed required to cause intrusion into the occupant volume of a consist with a CEM car leading is higher than the impact speed required to cause intrusion into the occupant volume of a consist with a conventional car leading. How much higher this impact speed is for the consist with a CEM car leading depends on how many CEM cars immediately follow the leading car. The results of these studies also show that crush zones are beneficial for both MU and push-pull service, and that CEM makes train crashworthiness nearly independent of the range of train lengths typically used in passenger service. 


\section{ACKNOWLEDGEMENTS}

This work was performed as part of the Equipment Safety Research Program sponsored by the Office of Research and Development of the Federal Railroad Administration. The authors thank Tom Tsai, Program Manager, and Claire Orth, Division Chief, Equipment and Operating Practices Research Division, Office of Research and Development, Federal Railroad Administration, for their support.

The scope of this paper ranges from collision simulations, to design development, to rail carbody construction, to fullscale testing. Eloy Martinez, Senior Engineer, Volpe Center, initiated and is monitoring the efforts to develop and fabricate the crush zones. Kristine Severson is leading the efforts to develop improved occupant protection in rows of passenger seats. Robert Rancatore, Project Leader, TIAX, LLC, is leading the effort to develop the cab car crush zone design, and to fabricate the crush zone components. TRA Associates is supporting TIAX in the design of the cab car crush zone. Ebenezer Rail Car is supporting TIAX in the construction of the crush zone components. Tom Roderick, Senior Technician and Joe Hanratty, Senior Technician, TTCI are integrating the crush zones into the cars. Gunars Spons, Federal Railroad Administration Resident Manager at the Transportation Technology Center, is managing the full-scale test effort.

\section{REFERENCES}

[1] National Transportation Safety Board, "Railroad Accident Report: Head-On Collision of Boston and Maine Corporation Extra 1731 East and Massachusetts Bay Transportation Authority Train No. 570 on Former Boston and Maine Corporation Tracks, Beverly, Massachusetts, August 11, 1981," NTSB-RAR-82-1, 1982.

[2] National Transportation Safety Board, "Collision of Burlington Northern Santa Fe Freight Train With Metrolink Passenger Train, Placentia, California, April 23, 2002" Railroad Accident Report NTSB/RAR-03-04, adopted on 10/7/2003.

[3] Tyrell, D., "Passenger Rail Train-to-Train Impact Test Volume I: Overview and Selected Results," U.S. Department of Transportation, DOT/FRA/ORD-03/17.I, July 2003.

[4] Tyrell, D., K. Severson, A.B. Perlman, "Single Passenger Rail Car Impact Test Volume I: Overview and Selected Results," U.S. Department of Transportation, DOT/FRA/ORD00/02.1, March 2000.

[5] Jacobsen, K., Tyrell, D., Perlman, A.B., "Impact Test of a Crash Energy Management Passenger Rail Car," RTD200466045, April 2004.

[6] Tyrell, D., K. Severson, A.B. Perlman, "Passenger Rail Two-Car Impact Test Volume I: Overview and Selected Results," U.S. Department of Transportation, DOT/FRA/ORD01/22.I, January 2002.

[7] Jacobsen, K., Tyrell, D., Perlman, A.B., "Impact Tests of Crash-Energy Management Passenger Rail Cars: Analysis and Structural Measurements," American Society of Mechanical Engineers, Paper No. IMECE2004-61252, November 2004.

[8] Jacobsen, K., Tyrell, D., Perlman, A.B., "Grade-Crossing Impact Tests: Collision Dynamics," ASME/IEEE Paper No. RTD2003-1655, April 2003.
[9] Martinez, E., Tyrell, D., Zolock, J. "Grade-Crossing Impact Tests: Car Crush," ASME/IEEE Paper No. RTD20031656, April 2003.

[10] Association of American Railroads, Technical Services Division, Mechanical Section - Manual of Standards and Recommended Practices, "Locomotive Crashworthiness Requirements, Standard S-580," Adopted: 1989, Revised, 1994.

[11] Martinez, E., Tyrell, D., Perlman, A.B., "Development of Crash Energy Management Designs for Existing Passenger Rail Vehicles," American Society of Mechanical Engineer, Paper No. IMECE2004-61601, November 2004.

[12] Mayville, R., Stringfellow, R., Johnson, K., Landrum, S., "Crashworthiness Design Modifications for Locomotive and Cab Car Anticlimbing Systems," U.S. Department of Transportation, DOT/FRA/ORD-03/05, February 2003.

[13]Zolock, J., Tyrell, D., "Locomotive Cab Occupant Protection," American Society of Mechanical Engineers, Paper No. IMECE2003-44121, November 2003.

[14] Stringfellow, R., Rancatore, R., Llana, P., Mayville, R., "Analysis of Colliding Vehicle Interactions for the Passenger Rail Train-to-Train Impact Test," American Society of Mechanical Engineers, Paper No. RTD2004-66037, April 2004.

[15] Severson, K., Parent, D., Tyrell, D., “Two-Car Impact Test of Crash-Energy Management Passenger Rail Cars: Analysis of Occupant Protection Measurements," American Society of Mechanical Engineers, Paper No. IMECE2004-61249, November 2004.

[16] Tyrell, D.C., Severson, K.J., Marquis, B.J., "Analysis of Occupant Protection Strategies in Train Collisions," ASME International Mechanical Engineering Congress and Exposition, AMD-Vol. 210, BED-Vol. 30, pp. 539-557, 1995.

[17] Tyrell, D., Zolock, J., VanIngen-Dunn, C., "Rail Passenger Equipment Collision Tests: Analysis of Occupant Protection Measurements," Rail Transportation, American Society of Mechanical Engineers, RTD-Vol. 19, 2000.

[18] VanIngen-Dunn, C., "Single Passenger Rail Car Impact Test Volume II: Summary of Occupant Protection Program," US Department of Transportation, DOT/FRA/ORD-00/02.2, March 2000.

[19] Tyrell, D.C., Perlman, A.B., "Evaluation of Rail Passenger Equipment Crashworthiness Strategies," Transportation Research Record No. 1825, pp. 8-14, National Academy Press, 2003.

[20] Severson, K., Tyrell, D., Perlman, A.B. , "Analysis of Collision Safety Associated with Conventional and Crash Energy Management Cars Mixed Within a Consist," American Society of Mechanical Engineers, Paper No. IMECE200344122, November 2003.

[21] Priante, M., Tyrell, D., Perlman, A.B., "The Influence of Train Type, Car Weight, and Train Length on Passenger Train Crashworthiness," American Society of Mechanical Engineers, Paper No. RTD2005-70042, March 2005. 